\title{
The Level of Special Education Teachers' Technological Pedagogy and Content Knowledge, Teaching Style, Self-efficacy and Competency
}

\author{
Rubashini Ramakrishnan, Norshidah Mohamad Salleh*, Aliza Alias \\ Faculty of Education, Universiti Kebangsaan Malaysia, 43600, Bangi, Selangor, Malaysia
}

Received July 30, 2020; Revised October 7, 2020; Accepted October 30, 2020

\begin{abstract}
Cite This Paper in the following Citation Styles
(a): [1] Rubashini Ramakrishnan, Norshidah Mohamad Salleh, Aliza Alias, "The Level of Special Education Teachers' Technological Pedagogy and Content Knowledge, Teaching Style, Self-efficacy and Competency," Universal Journal of Educational Research, Vol. 8, No. 11A, pp. 89 - 96, 2020. DOI: 10.13189/ujer.2020.082111.
\end{abstract}

(b): Rubashini Ramakrishnan, Norshidah Mohamad Salleh, Aliza Alias (2020). The Level of Special Education Teachers' Technological Pedagogy and Content Knowledge, Teaching Style, Self-efficacy and Competency. Universal Journal of Educational Research, 8(11A), 89 - 96. DOI: 10.13189/ujer.2020.082111.

Copyright $\odot 2020$ by authors, all rights reserved. Authors agree that this article remains permanently open access under the terms of the Creative Commons Attribution License 4.0 International License

\begin{abstract}
Teachers play an essential role in implementing the ultimate goal of education by producing insightful human capital in line with the goals of the Pelan Pembangunan Pendidikan Malaysia (PPPM) 2013-2025. This effort is also the main responsibility of special education teachers in improving a learning process that satisfies the specific necessities of special needs students. Special education teachers require to furnish themselves with a wide assortment of knowledge and skills so that quality education can be applied to students with special needs. Therefore, this study investigates the level of technological pedagogy and content knowledge, teaching style, self-efficacy and competency among special education teachers. This research employs a quantitative approach applying the survey method. In this research, 229 special education teachers from vocational schools are involved as a sample. The collected data were analysed, adopting the SPSS application to get the mean and standard deviation. The results confirm that the technological pedagogy and content knowledge (mean $=4.96)$, teaching style $($ mean $=5.44)$, self-efficacy $($ mean $=6.92)$ and competency (4.12) are at high level. This study carries positive impacts on teachers' task in enhancing the quality of their teaching profession.
\end{abstract}

Keywords Technological Pedagogy and Content Knowledge, Teaching Style, Self-efficacy, Competency, Special Education Teacher

\section{Introduction}

Education is an important element in the development of countries and nations. The country's education system is intended to produce quality citizens and to fulfil the country's goals. Advances in the educational system are continually growing and necessary as there are differences and demands at the national level and swift growth globally [39]. Influence of changes that will discursively impact student accomplishment, especially at school level and this involves special needs students. Consequently, the government has presented education in a manner to provide the needs of the students in line with the expansion of education at the national level. The curriculum is designed not only to produce knowledgeable citizens but also skillful in various fields. Ministry of Education (MOE) provides the vocational education curriculum for special needs students as they have the physical capacity to be trained in order to practice the skills acquired after graduation [17]. Trained teachers are required to actualize government goals. Besides, teachers must also have the confidence to keep up with the developments in the national education system. Teachers who teach special needs students in schools, especially in vocational education schools have to furnish themselves with a broad array of knowledge and 
skills. They should be well-versed of the technological pedagogy and content knowledge, teaching style, self-efficacy and competency as planned in the Standard Kualiti Pendidikan Malaysia Gelombang 2
(SKPMg2)[18].

Additionally, they need to possess the knowledge and skills in the subjects taught, even the teachers need to know about the special needs students themselves and the necessary learning support [29]. Teachers' mastery in integrating technological pedagogy and content knowledge is necessary because teachers are accountable for the learning activities of special needs students in schools. However, despite the emphasis on the important given to special education teachers, it is found that there are various problems still exist. Among them are teachers who teach special needs students found lacking confidence to diversify teaching styles, lack of knowledge in terms of pedagogy and content, difficulty in integrating the use of technology in teaching and less prepared to teach the students according to their disability which cause teachers' competency unsatisfaction $[7,8,33,36]$. This issue clarifies the importance of content pedagogical technology knowledge, teaching style and self-efficacy as well as teacher competency.

Previous studies reveal that special education teachers are less skilled in the adoption of technology in teaching which becomes less attractive and boring $[8,34]$. Teachers' knowledge in technology, pedagogy and content is important to integrate into special education so that the potential of special needs students can be improved and facilitate them to become independent [19]. Teachers need to equip themselves with technology-related knowledge so that these components can be combined with pedagogy and content when teaching. Rather than that, teachers' teaching style is also one of the elements that need to be considered so that effective teaching can be presented to students. Teachers are found to be less aware of the teaching objectives provided because they do not take into account the special needs students' ability [33]. Teachers must change their teaching styles if they notice special needs students are starting to lose focus and become stultify [12] during the teaching and learning process. Teachers need to diversify their teaching styles according to the needs and abilities of the special needs students so that the teaching environment is more enjoyable and active learning can be created.

Self-efficacy also plays a vital role because teachers' personal beliefs can positively impact students' achievement, especially special needs students. Teachers with low self-efficacy are incapable of presenting quality education in special education [7]. Conversely, if teachers have positive self-efficacy, teachers can offer better teaching strategies $[15,27]$ and engage special needs students in learning with more effective [24]. High self-efficacy of teachers can promote special needs students' eagerness to learn more. The same observation applies to competency that is being the principal pillar of the teaching profession. Teachers with less competency will negatively impact the social, emotional and behavioral of special needs students [36]. If teachers are highly competency, an excellent social relationship between teachers and students can be built [3]. Teachers need great levels of academic and professional skills so that special needs students can master new knowledge and practice it after school.

Ergo, research on the level of technological pedagogy and content knowledge, teaching style, self-efficacy and competency among special education teachers are explored. Four research questions were developed:

1. What is the level of technological pedagogy and content knowledge among teachers in vocational special education?

2. What is the level of teaching style among teachers in vocational special education?

3. What is the level of self-efficacy among teachers in vocational special education?

4. What is the level of competency among teachers in vocational special education?

\section{Methods}

The survey was done at a vocational special education secondary schools in Malaysia. The study sample $(\mathrm{N}=$ 229) was selected as the sample for this study. Sample selection is based on proportionate strata random sampling followed by simple random sampling for each school sub-sample. The sample selection is also based on criteria that only teachers who teach in vocational special education schools including academic and technical subjects are involved except administrators.

There were four research instruments applied and adapted in this study. The instruments are Technological Pedagogy and Content Knowledge [23], Grasha Teaching Style [10], Teacher Sense of Efficacy Scale (TSES) [1] and SKPMg2 [18]. This survey includes five parts. Part A is Respondent's Personal Profile Information with eight items. Part B is Technological Pedagogy and Content Knowledge with four subconstructs. The answer choices for each item were based on a five-point Likert scale, which strongly disagrees to strongly agree. Part $\mathrm{C}$ is a Teaching Style with five subconstructs. The answer choices for each item were based on a seven-point Likert scale, which strongly disagrees to strongly agree. Part D is Self-Efficacy with three subconstructs. The answer options for each item were based on a nine-point Likert scale, which is not very confident to very confident. Part E is Competency with five subconstructs. The answer choices for each item were based on a five-point Likert scale, which is not very confident to very confident. 


\section{Data Analysis}

\subsection{Paper Title}

Questionnaire responses were analysed using the Statistical Packages for the Social Sciences (SPSS) version 23.0. Descriptive statistics of mean and standard deviation were applied to analyse the results of this study. To define the level of each variable, mean values were categorized according to varying mean scores per section, as shown in tables 1 to 3 .

Table 1. Interpretations of mean scores for the technological pedagogy and content knowledge and competency level of vocational special education teachers.

\begin{tabular}{|c|c|}
\hline Mean scores & Interpretations \\
\hline $1.00-1.89$ & Very low \\
\hline $1.90-2.69$ & Low \\
\hline $2.70-3.49$ & Moderate \\
\hline $3.50-4.29$ & High \\
\hline $4.30-5.00$ & Very High \\
\hline
\end{tabular}

Source: Adaptation from Bahagian Perancangan dan Penyelidikan Dasar Pendidikan (BPPDP) [16]

Table 2. Interpretations of mean scores for the teaching style level of vocational special education teachers

\begin{tabular}{|c|c|}
\hline Mean scores & Interpretations \\
\hline $1.00-3.00$ & Low \\
\hline $3.01-5.00$ & Moderate \\
\hline $5.01-7.00$ & High \\
\hline
\end{tabular}

Source: Adaptation from Nik Yusof [26]

Table 3. Interpretations of mean scores for the self-efficacy level of vocational special education school teachers

\begin{tabular}{|c|c|}
\hline Mean scores & Interpretations \\
\hline $1.00-1.80$ & Very low \\
\hline $1.81-3.60$ & Low \\
\hline $3.61-5.40$ & Moderate \\
\hline $5.41-7.20$ & High \\
\hline $7.21-9.00$ & Very High \\
\hline
\end{tabular}

Source: Adaptation from Nik Aida [1]

\section{Results}

The results of this study are based on the research questions to study the level of technological pedagogy and content knowledge, teaching style, self-efficacy and competency of vocational special education teachers.

\subsection{Level of Technological Pedagogy and Content Knowledge}

Table 4 shows the mean scores for the level of the technological pedagogy and content knowledge of vocational special education teachers. Generally, it was discovered that the level of technological pedagogy and content knowledge was high (mean=3.96, sd=.340). The technological pedagogy knowledge sub construct had a mean of 3.93 with a standard deviation of .482 while the subconstruct of technological content knowledge had a mean of 3.88 with a standard deviation of .497. The pedagogical content knowledge subconstruct had a mean of 4.03 with a standard deviation of .476 while the sub construct of technological pedagogy content knowledge has a mean of 3.94 with a standard deviation of .504. From the findings, teachers' level of knowledge was found to be higher in pedagogical content knowledge comparison to other subconstructs. This outcome signifies that teachers in vocational special education have good knowledge of technology, pedagogy and content.

Table 4. Level of technological pedagogy and content knowledge

\begin{tabular}{|c|c|c|c|}
\hline Subconstructs & Mean & $\begin{array}{c}\text { Standard } \\
\text { Deviation }\end{array}$ & $\begin{array}{c}\text { Interpretations } \\
\text { Level }\end{array}$ \\
\hline $\begin{array}{c}\text { Technological } \\
\text { Pedagogy } \\
\text { Knowledge }\end{array}$ & 3.93 & 0.482 & High \\
\hline $\begin{array}{c}\text { Technological } \\
\text { Content Knowledge }\end{array}$ & 3.88 & 0.497 & High \\
\hline $\begin{array}{c}\text { Pedagogical Content } \\
\text { Knowledge }\end{array}$ & 4.03 & 0.476 & High \\
\hline $\begin{array}{c}\text { Technological } \\
\text { Pedagogy Content } \\
\text { Knowledge }\end{array}$ & 3.94 & 0.504 & High \\
\hline
\end{tabular}

\subsection{Level of Teaching Style}

Table 5. Level of teaching style

\begin{tabular}{|c|c|c|c|}
\hline Subconstructs & Mean & $\begin{array}{c}\text { Standard } \\
\text { Deviation }\end{array}$ & $\begin{array}{c}\text { Interpretation } \\
\text { Level }\end{array}$ \\
\hline Expert & 5.40 & 0.764 & High \\
\hline $\begin{array}{c}\text { Formal } \\
\text { Authority }\end{array}$ & 5.44 & 0.799 & High \\
\hline $\begin{array}{c}\text { Personal } \\
\text { Model }\end{array}$ & 5.48 & 0.734 & High \\
\hline Facilitator & 5.51 & 0.733 & High \\
\hline Delegator & 5.37 & 0.764 & High \\
\hline
\end{tabular}

Table 5 presents the mean scores for the teaching style of teachers in vocational special education. Overall it was found that the level of teaching style was high for all teaching styles (mean $=5.44, \mathrm{sd}=.657$ ). The subconstruct of expert had a mean of 5.40 with a standard deviation of .764 while an authority formal subconstruct had a mean of 5.44 with a standard deviation of .799. The subconstruct of personal model had a mean of 5.48 with a standard deviation of .734 while the facilitator subconstruct had a mean of 5.51 with a standard deviation of .733. The subconstruct of delegator had a mean of 5.37 with a standard deviation of .764 . Based on the results, the level of facilitator teaching style is found to be higher than other teaching styles. It points out that teachers in vocational special education specialize in teaching using 
variety of teaching styles.

\subsection{Level of Self-efficacy}

Table 6. Level of self-efficacy

\begin{tabular}{|c|c|c|c|}
\hline Subconstructs & Mean & $\begin{array}{c}\text { Standard } \\
\text { Deviation }\end{array}$ & $\begin{array}{c}\text { Interpretations } \\
\text { Level }\end{array}$ \\
\hline $\begin{array}{c}\text { Student } \\
\text { Engagement }\end{array}$ & 6.83 & 1.023 & High \\
\hline $\begin{array}{c}\text { Instructional } \\
\text { Strategies }\end{array}$ & 6.92 & 1.050 & High \\
\hline $\begin{array}{c}\text { Classroom } \\
\text { Management }\end{array}$ & 7.02 & 1.048 & High \\
\hline
\end{tabular}

Table 6 displays the mean scores for the self-efficacy level of teachers in special vocational education. Overall, teachers' self-efficacy was found to be high for all the subconstructs $\quad($ mean $=6.92, \quad \mathrm{sd}=.974)$. The student engagement subconstruct had a mean of 6.83 with a standard deviation of 1.023 while the subconstruct of instructional strategies had a mean of 6.92 with a standard deviation of 1.05. The classroom management subconstruct had a mean of 7.02 with a standard deviation of 1.048. From the data obtained, the effectiveness of teachers in vocational special education is higher in the classroom management aspect.

\subsection{Level of Competency}

Table 7. Level of competency

\begin{tabular}{|c|c|c|c|}
\hline Subconstructs & Mean & $\begin{array}{c}\text { Standard } \\
\text { Deviation }\end{array}$ & $\begin{array}{c}\text { Interpretations } \\
\text { Level }\end{array}$ \\
\hline $\begin{array}{c}\text { Teacher as } \\
\text { Planner }\end{array}$ & 4.09 & 0.559 & High \\
\hline $\begin{array}{c}\text { Teacher as } \\
\text { Controller }\end{array}$ & 4.12 & 0.507 & High \\
\hline $\begin{array}{c}\text { Teacher as } \\
\text { Adviser }\end{array}$ & 4.15 & 0.514 & High \\
\hline $\begin{array}{c}\text { Teacher as } \\
\text { Assessor }\end{array}$ & 4.10 & 0.537 & High \\
\hline $\begin{array}{c}\text { Teacher as } \\
\text { Motivator }\end{array}$ & 4.13 & 0.573 & High \\
\hline
\end{tabular}

Table 7 exposes the mean scores for competency levels of teachers in vocational special education. Generally, teacher competency was found to be high (mean $=4.12$, $\mathrm{sd}=.468$ ). The subconstruct as a planner had a mean of 4.09 with a standard deviation of .559 while the subconstruct as a controller had a mean of 4.12 with a standard deviation of .507. The subconstruct as an adviser had a mean of 4.15 with a standard deviation of .514 while the subconstruct as an assessor had a mean of 4.10 with a standard deviation of .537. The subconstruct as a motivator had a mean of 4.13 with a standard deviation of .573. From the findings, the level of competency of teachers in vocational special education is higher in terms of teachers as adviser in comparison to other constructs.

\section{Discussion}

The teaching profession is a significant concern that every teacher should take into account. Teachers need to have in-depth knowledge in various aspects so that appropriate teaching can be carried out according to the abilities of students. Technological pedagogy and content knowledge is one of the components that should be incorporated into the daily teaching of all teachers. The findings show that special education teachers have a high level of technological pedagogy and content knowledge. All subconstructs namely technological pedagogy knowledge, technological content knowledge, pedagogical content knowledge and technological pedagogy content knowledge are also high. Subconstruct of pedagogical content knowledge is found to be in the highest rank than other subconstructs. These teachers have extensive knowledge in selecting information technology, hardware and teaching using technological pedagogy and content knowledge in their daily teaching. Teachers are also found to be able to use this technological pedagogy and content knowledge approach to meet the specific needs of students.

The outcomes of this study are parallel with previous research decisions such as [4, 5] which present that teachers' technological pedagogy and content knowledge is at a high level. The findings of the study by [5] found that teachers are proficient in the use of technology and can apply technology-based teaching in the teaching and learning process. Likewise, a study by [4] found that pedagogical content knowledge subconstructs were an element that teachers had mastered better compared to other subconstructs. References [4] also found that special education teachers who teach special needs students have mastered knowledge that covers technology, pedagogy and content. These studies have found that teachers use technology elements in their teaching as well as knowledge of computer hardware and devices.

In conclusion, it is found that teachers who teach special needs students have good technological pedagogy and content knowledge and are able to apply these elements in their teaching. The findings of this study support the study of [9] which emphasizes the importance of knowledge elements that include technology, pedagogy and content among teachers. Based on the research, technological pedagogy and content knowledge is one of the key elements in the development of teacher professionalism in terms of knowledge, understanding and skills. The study also found that teachers use a lot of knowledge in technological pedagogy, technological content, pedagogical content as well as technological pedagogy content in teaching. The combination of these elements will make teachers more attentive and take into account factors that will help students with special needs to learn more enthusiastically. However, aspects of technological content knowledge need to be taken into account as this subconstruct is found to be at a least rank.

Therefore, to address these shortcomings, teachers need to broaden their knowledge and understanding of the use 
of technology with appropriate teaching tools. Moreover, they need to select technologies that can be used to enhance the understanding of the subjects being taught. In addition, teachers also need to use technology more frequently in teaching so that the practical knowledge helps to provide excellence in teaching and quality education to the students. The findings of this study are in line with the recommendations of [21] that emphasize the integration of information and communication technologies. This interest led [21] to add an important component of technology to pedagogical content knowledge, which led to the development of Technological Pedagogy and Content Knowledge Model. Therefore, the findings of this study prove that teachers who teach students with special needs also emphasize knowledge that includes elements of technology, pedagogy and content.

Next is the teaching style factor that special education teachers need to master as one of the elements required in the development of their professionalism. The teaching style of the teacher here is more on the pattern of teaching or behavior that the teacher promotes during the teaching session. Even this aspect of teaching style comes naturally from the teacher itself and it is difficult to change. The results show that the teaching style of special education teachers who are teaching special needs students is at a high level. In fact, each of the subconstructs namely expert, formal authority, personel model, facilitator and delegator are also at the high level. The teaching style of facilitator was found to be in the highest rank than other subconstructs. These teachers were found to be more likely to use facilitator teaching style and personel model teaching style than other teaching styles. Teachers are also found to be able to respond in their own way of teaching when students need help and set specific criteria to guide students so that they can achieve the appropriate knowledge throughout their learning. Teachers also provide opportunities for students to actively participate in learning sessions.

For the teaching style, the findings are similar to the study by $[2,11]$ who found that the teaching style of teachers who teach special needs students is at a high level. Similarly, the findings of [30] found that subconstruct of delegator teaching style was at a least rank than other subconstructs. However, the findings of the study by [25] stated that the level of teachers teaching style was in lowest rank for the personel model and facilitator subconstructs, which was the highest subconstruct in this study. Similarly, a study by [22] found that the teaching style of expert, personel model and facilitator was at the average level while the formal authority teaching style was at a low level. The findings of this study showed that every teacher has their own teaching style and teachers present that style in their own style.

The summary found that teachers who teach students with special needs are able to present a creative and variety of teaching styles. The findings of this study support the study of $[2,11]$ that discusses the importance of teaching style elements among teachers and students. According to their research, teaching style is an important element in the development of teacher professionalism in terms of values and skills. This aspect is similar to this study where the teaching style is at a high level because teachers can adapt the teaching style to the specific needs of students. In fact, the study also found that various teaching styles such as expert, formal authority, personel model, facilitator and delegator can attract students to give their full attention to the process of teaching and learning. This is due to the variety of teaching styles that can influence students' academic and psychological learning performance when teachers use their favourite teaching styles. However, the element of teaching style of the delegator should be noted as this subconstruct is found to be at the lowest rank.

Therefore, to overcome this problem, teachers need to use the delegator's teaching style more effectively so that students do not rely solely on the teacher instead of trying to do the assigned tasks with minimal supervision. In addition, teachers need to be consulted only when needed and teachers need to provide the opportunity for students to act on their decision making for more flexible learning. The findings of this study are in line with [10] model which argues that each teacher has his or her own style of teaching with varying degrees of ability. In fact, according to [10], this style of teaching has its own essence and purpose that will help to increase students focus and attention. Therefore, the findings of this study support [10] finding that special education teachers who teach special needs students to practice different teaching styles according to the personal characteristics of the teachers as well as their potential.

In addition, self-efficacy is also one of the factors that help teachers improve their self-confidence in facing various challenges in education. Teacher self-efficacy means teachers' personal beliefs about what can be controlled and implemented in daily life. When a teacher has high self-efficacy then the teacher can perform whatever task he or she is assigned successfully. Teacher with high self-efficacy is able to diversify teaching styles according to the abilities of students [6]. Findings on the self-efficacy of teachers who teach special needs students are at high level. The findings show that the three subconstructs of self-efficacy namely student engagement, instructional strategies and classroom management are also at high level. The classroom management subconstruct is ranked highest compared to other subconstructs. This shows that the ability of teachers in managing special needs students' classes is excellent. Although this class is made up of various categories of students, teachers are able to control students' behaviour and ensure that there is appropriate classroom management for all categories. At the same time, teachers 
can also predict students behaviour that may disrupt other students or the teaching process and take appropriate steps by equipping themselves with positive self-efficacy or self-confidence.

References by [3, 20] found that high levels of teacher self-efficacy actually had a strong impact on special needs students' stance. The findings of this study are parallel with their findings where the level of teacher self-efficacy is at a very high level. Teachers' high self-efficacy is required to diminish the weaknesses when teaching special needs students [24, 37]. Self-efficacy represents a vital position in every teacher because his/her confidence can grant an engaging learning atmosphere. The study by [14] is consistent with the results of this study which have high mean values for all subconstructs. However, the study found that subconstruct of instructional strategies had the highest rank compared to other subconstructs. Similarly, a study by [31] found that subconstructs of classroom management and student engagement had a high level. However, [31] study found that subconstruct of instructional strategies had a moderate level. Although the findings showed that each subconstruct has different levels but the findings showed that these teachers had positive self-efficacy.

In conclusion, it was found that these teachers had good self-efficacy and were able to present the features needed in teaching to the special needs of students. The findings of this study supported the study of [3] who emphasized the importance of self-efficacy elements among teachers. According to their research, self-efficacy is an important element in the development of teacher professionalism in terms of practice and values. This aspect is in line with this study, where the effectiveness of teachers is high because teachers can modify their teaching to the students' abilities. Even teachers teach by taking into account aspects such as student engagement, using a variety of instructional strategies and managing the classroom as best they can. However, the aspect of student engagement is to be taken in account because the level of the subconstruct is found to be in the least rank than other subconstruct. Teachers need to be more aware of their students' abilities and so that a learning environment that engages all students can be created.

This is important on dealing with students who have problems in learning and for helping students to actively engage throughout the lesson. Teachers can also foster student creativity especially among less motivated students and help enhance students understanding of what they are learning. The findings of this study are in line with the recommendations of [35] who developed the Self-Efficacy Model based on the importance of teachers' positive attitude or behavior in performing any given task. Even the Model of Self-Efficacy by [35] also considers teachers' abilities in what teachers can do with confidence. Therefore, the findings of this study prove that teachers who teach students with special needs have a high degree of self-efficacy which is high confidence in themselves.

Next is a factor of competency that encompasses the values of professionalism, knowledge, understanding and skills. These elements are needed to produce a teacher who is able to overcome any challenges and obstacles in education with a positive attitude [28]. Findings on the factors of competency of education teachers who teach special needs students are found to be as high as other constructs. All the five subconstructs which were teacher as planner, controller, adviser, assessor and motivator. The subconstruct teacher as adviser is ranked highest compared to other subconstructs. These teachers are found to have a character as adviser than other characters. In fact, teachers are more likely to be able to teach and assist students in their teaching. Teachers are also more concerned with giving praise, words of encouragement and stimulating the minds and abilities of students to deepen the lessons taught.

Reference [2] emphasizes the importance of the element of competency among teachers. According to their research, competency does not only need attention in regards to the development of professionalism but also on ways in which a teacher should emphasize and assess the skills. This aspect is similar to this study where the level of teacher competency is very high as teachers can implement and evaluate teaching in the capacity special needs students. Studies by [13] also found that all subconstructs of this competency were at a high level. In fact, the findings of the study are in line with the findings of this study for the subconstructs as adviser and motivators which are at highest rank than the other subconstructs. In addition, the findings of the study by [38] also found that competency of teachers was at a high level for the entire subconstructs. The study by [38] stated that subconstruct teacher as controller is at first ranked while subconstruct as assessor at the second ranked. The findings of this past study showed that teachers have good and high competencies that assist them in improving their teaching profession.

The conclusion is that these teachers have good competencies and are able to apply the features needed to improve their quality of teaching. The findings of this study support the study of [2] which emphasizes the importance of the element of competency among teachers. According to the research, competency not only needs to be given attention in terms of the development of professionalism but also how a teacher should practice and evaluate a skill. This aspect is in line with this study where the level of teacher competency is at a high level because teachers can implement and evaluate teaching according to student ability.

However, the characteristics of teachers as planner need to be taken as the subconstruct is found to be at the lowest rank. Teachers as planner is important because teachers begin each lesson by preparing the lesson plans every day. The importance of this character should be take into 
account so that teachers can prepare good teaching materials for the students. The findings of this study are also in line with [32] Iceberg Model that emphasizes the elements of competency needed to achieve positive professionalism. In fact, the Iceberg Model [32] highlights the elements of skill, knowledge and personal values that a person must attain in order to succeed. In line with the recommendations of [32], the findings of this study also prove that special education teachers actually have a high degree of competency in themselves.

\section{Conclusions}

Overall, the research carried out among vocational special education school teachers is at a great level for all the variables. Teachers are perceived to be aware of their respective responsibilities in reaching the significant aims of their teaching profession. Teachers need to keep striving for knowledge in all phases of academics and skills. Therefore, teachers need to be more conscious of the types and specifications of courses needed to keep up with the current momentum.

This study can be referred by disparate parties, especially policy practitioners, informing the implementation of vocational education for special needs students and the teachers. The elements of technological pedagogy and content knowledge, teaching style, self-efficacy and competency need to be highlighted in outlining a guide that will serve as reference material for teachers. Also, the findings present powerful implications for teachers who teach special needs students so that a quality education system can be provided to them. The findings of this study have practical implications for MOE and school administrators. The results of the study found that technological pedagogy and content knowledge, teaching style, self-efficacy and competence contribute to teachers' excellence as enshrined in SKPMg2 [18]. MOE and school administrators need to take these factors into account when assessing teachers' capabilities and abilities towards improving teachers' professionalism. Implementation of quality vocational education needs to be practiced in daily teaching so that skillful and knowledgeable special needs students can be produced. The findings also highlight how the teaching profession can be enhanced in a better way. Teachers need to be more responsible towards their duties as an ideal teacher so that their services are optimized by everyone, including special needs students, parents, schools, community and the country.

As a suggestion for further research, studies related to technological pedagogy and content knowledge, teaching style, self-efficacy and competency of vocational special education school teachers could be expanded by looking at perspectives of educational options, gender and teaching experience. The dominant factors and the influence on the teaching profession can also be analyzed.

\section{Acknowledgement}

This research was partially funded by: UKM Grant GG-2019-003 and PP-FPEND-2020. Thank you.

\section{REFERENCES}

[1] Ami N. A. S. N. Z. Hubungan sokongan guru besar, efikasi kendiri, efikasi kolektif dengan komitmen kerja guru pendidikan khas, PhD's Thesis, Bangi, Universiti Kebangsaan Malaysia, 2016.

[2] Blândul V. S. Bradea A. Developing psychopedagogical and methodical competences in special / inclusive education teacher, Problems of Education in the 21st Century, Vol.75, No.4, 335-344, 2017.

[3] Breeman L. D. Wubbels T. van Lier P. A. C. Verhulst, F. C. van der Ende J. Maras A. ... Tick, N. T. Teacher characteristics, social classroom relationships, and children's social, emotional, and behavioral classroom adjustment in special education, Journal of School Psychology, Vol.53, No.1, 87-103, 2015.

[4] Demirok M. S. Baglama B. Examining technological and pedagogical content knowledge of special education teachers based on various variables, TEM Journal, Vol.7, 507-512, 2018.

[5] Dong Y. Chai C. S. Sang G. Y. Koh J. H. L. Tsai C. C. Exploring the profiles and interplays of pre-service and in-service teachers' technological pedagogical content knowledge (TPACK) in China, Educational Technology \& Society, Vol.18, No.1, 158-169, 2015.

[6] Du Plessis J. Ewing B. Reasonable adjustments in learning programs: teaching length, mass and capacity to students with intellectual disability. Universal Journal of Educational Research, Vol.5, No.10, 1795-1805, 2017.

[7] Dunst C. J. Bruder M. B. Preservice professional preparation and teachers' self-efficacy appraisals of natural environment and inclusion practices, Teacher Education and Special Education, Vol.37, No.2, 121-132, 2014.

[8] Giles R. M. Kent A. M. An investigation of preservice teachers' self-efficacy for teaching with technology, Asian Education Studies, Vol.1, No.1, 32-40, 2016.

[9] Gómez-Arizaga M. P. Conejeros-Solar M. L. Marti A. How good is good enough? A community-based assessment of teacher competencies for gifted students, SAGE Open, Vol.6, No.4, 1-14, 2016.

[10] Grasha A. F. Teaching with Style. CA, United States of America, Alliance Publishers, 1996.

[11] Gunarhadi. Anwar S. M. Andayani T. R. Shaari A. S. The effect of cluster-based instruction on mathematic achievement in inclusive schools, International Journal of Special Education, Vol.31, No.1, 78-87, 2016. 
[12] Gunarhadi. Sunard. Andayani T. R. Supratiwi M. Breaking academic inclusionthrough cluster-basedinstruction (An approach to differentiated instruction for students with disabilities in inclusive schools), Journal of Engineering and Applied Science, Vol.13, No.8, 2221-2225, 2018.

[13] Hassan W. N. W. Yusoff N. M. 'SKPMg2' (Standard 4) as tools to upgrade teachers' teaching quality, Journal of Educational Research and Indigeneous Studies, Vol.1, No.1, 2019.

[14] Ismail A. Yen L. H. Abdullah A. G. K. Komuniti pembelajaran profesional dan efikasi kendiri guru sekolah menengah di Pulau Pinang, Jurnal Kepimpinan Pendidikan, Vol.2, No.1, 1-12, 2015.

[15] Katz J. Implementing the three block model of universal design for learning: Effects on teachers' self-efficacy, stress, and job satisfaction in inclusive classrooms $\mathrm{K}-12$, International Journal of Inclusive Education, Vol.19, No.1, $1-20,2015$

[16] Kementerian Pendidikan Malaysia. Bahagian Perancangan dan Penyelidikan Dasar Pendidikan, Pelan Induk Pembangunan Pendidikan 2006-2010. Putrajaya, 2006

[17] Kementerian Pendidikan Malaysia. Transformasi Pendidikan Vokasional. Pelan Pembangunan Pendidikan Malaysia (PPPM) 2013-2020, Putrajaya, 2012.

[18] Kementerian Pendidikan Malaysia. Standard Kualiti Pendidikan Malaysia Gelombang 2, Jemaah Nazir dan Jaminan Kualiti, Putrajaya, 2017.

[19] Liu G. Z. Wu N. W. Chen Y. W. Identifying emerging trends for implementing learning technology in special education: A state-of-the-art review of selected articles published in 2008-2012, Research in Developmental Disabilities, Vol.34, No.10, 3618-3628, 2013.

[20] Lowrey K. A. Hollingshead A. Howery K. Bishop J. B. More than one way: Stories of UDL and inclusive classrooms, Research and Practice for Persons with Severe Disabilities, Vol.42, No.4, 225-242, 2017.

[21] Mishra P. Koehler M. J. Technological pedagogical content knowledge: A framework for teacher knowledge, Teachers college record, Vol.108, No.6, 1017-1054, 2006.

[22] Mubashira K. Mumtaz A. Aroona H. Teaching styles of secondary school English teachers and learning styles of their students and relationship of teaching learning style match with students' achievement, Bulletin of Education and Research, Vol.39, No.3, 203-220, 2017.

[23] Mustafa H. M. A. Hubungan amalan pengintegrasian teknologi maklumat dan komunikasi (TMK) dengan pengetahuan teknologi pedagogi kandungan (PTPK), gaya pengajaran dan kepercayaan guru kemahiran hidup bersepadu, PhD's Thesis, Bangi, Universiti Kebangsaan Malaysia, 2017

[24] Narkon D. E. Wells J. C. Improving reading comprehension for elementary students with learning disabilities: UDL enhanced story mapping. Preventing School Failure: Alternative Education for Children and Youth, Vol.57, No.4, 231-239, 2013.

[25] Nawawi A. M. Mohd A. Saad N. M. Baharuddin J. Ismail S.
N. Hubungan antara gaya pengajaran guru dengan tahap ponteng sekolah menengah di daerah Bachok, Kelantan, Proceeding of ICECRS, 341-358, 2016.

[26] Nik Yusoff. N. M. R. Kemahiran mendengar bahasa Arab: Satu kajian di Sekolah Menengah Kerajaan Negeri, PhD's Thesis, Bangi, Universiti Kebangsaan Malaysia, 2004.

[27] Ramakrishnan R. Salleh N. M. Teacher's self-efficacy: A systematic review, International Journal of Academic Research in Business and Social Sciences, Vol.8, No.12, 2379-2402, 2018.

[28] Sabbah K. Kobari S. Ahmad M. A. Daher W. The effect of education for future program on teachers' competencies in a public school. Universal Journal of Educational Research, Vol.8, No.7, 2890-2897, 2020.

[29] Salleh N. M. Hassan N. J. Zainal K. The needs of modification teaching and learning Mathematics for students with visual impairment in primary school, Journal of Advanced Research in Dynamical and Control Systems, Vol.10, No.2, 1662-1668, 2018.

[30] Shaari A. S. Yusoff N. M. Ghazali I. M. Osman R. H. Dzahir N. F. M. The relationship between lecturers' teaching style and students' academic engagement, International Conference on Knowledge-Innovation-Excellence: Synergy in Language Research and Practice, Vol.118, No.2014, $10-20,2013$

[31] Shamsudin A. Abd Majid R. Efikasi kendiri guru sekolah dalam hospital di Malaysia, Journal of Social Science and Humanitis, e-Bangi, Vol.13, No.3, 20-28, 2018.

[32] Spencer L. M. Spencer S. M. Competence At Work. Models for Superior Performance, John Wiley \& Sons, Inc, 1993.

[33] Sweigart C. A. Landrum T. J. Pennington R. C. The effect of real-time visual performance feedback on teacher feedback: A preliminary investigation, Education and Treatment of Children, Vol.38, No.4, 429-450, 2015.

[34] Tondeur J. Pareja Roblin N. van Braak J. Voogt J. Prestridge S. Preparing beginning teachers for technology integration in education: Ready for take-off?, Technology, Pedagogy and Education, Vol.26, No.2, 157-177, 2017.

[35] Tschannen-Moran M. Hoy A.W. Teacher efficacy: Capturing an elusive construct, Teaching and Teacher Education, Vol.17, 783-805, 2001.

[36] Verschueren K. Kooman H. M. Y. Teacher-child relationships from an attachment perspective, Attachment and Human Development, Vol.14, No.3, 205-211, 2012.

[37] Yin L. C. Loreman T. Majid R. A. Alias A. The Dispositions towards loving pedagogy (DTLP) scale: Instrument development and demographic analysis, Teaching and Teacher Education, Vol.86, No.2019, 1-9, 2019.

[38] Zaaim K. Z. Nor M. Y. M. Surat S. Tahap kompetensi guru (pdpc) SKPMg2 dan tahap kemenjadian murid, International Journal of Education, Psychology and Counseling, Vol.4, No.27, 51-62, 2019

[39] Zainal K. Talib J. Idris F. Noor M. M. Salleh N. M. Developing Sustainable Education in Regional Australia, Victoria, Australia, Monash University, 99-116, 2014. 